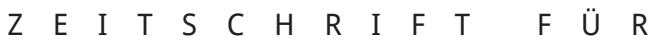

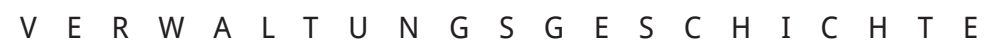

B A N D $3, \quad 20018$

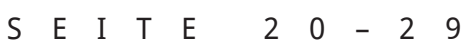

D O I : $10.2478 / \mathrm{ADH}$ I- $2018-0031$

\title{
"Monitor Yourself!« The Controlled Emotions of Spanish Office Holders in the Early Modern Period
}

\author{
ARNDT BRENDECKE
}

In late medieval and early modern Spanish tracts, one repeatedly encounters the ideal of a person "stripped of affects", who is suitable for the office precisely for this reason. Curiously, therefore, we find the ideal of an emotionless person long before the time in which civil servants even existed as a social group. It is also strange that we find this ideal of an emotionless office holder precisely in the place least expected in the field of traditional research. For Spain lacked important factors usually listed in research on state formation and on the emergence of a civil service as defined by Max Weber, including a successful Reformation, Calvinism, and its associated stoa reception. Spanish research on state formation has addressed the conundrum. Prompted by the work of José Antonio Maravall, reference has been made since the 1960 s to the rise of new, professional administrative elites from the outgoing Middle Ages. These so-called letrados, i.e. usually legally educated university graduates, generally of bourgeois origin, would appear to mark clearly the switch from classbased to functional criteria. To a certain extent, they represent the social substrate of Spanish state formation. The letrados also employed a rhetoric that suggested that they were mere function and dedicated themselves to the office selflessly, neutrally and disinterestedly. The concept of sdisinterest (desinterés) marked this new service mentality. It seems to attest to a burgeoning awareness of the state. ${ }^{1}$ In the meantime, however, this suggestive image has been shaken profoundly by a younger generation of historians, driven by new approaches in social history originating in France. They identified the enormous extent to which the letrados were de facto integrated in social networks, how quickly they adapted to new demands by the court, how much they shielded themselves from other young, ambitious university graduates and so on. The standing and the political power of the letrados were by no means based on the ever-stricter adherence to administrative instructions and the evermore successful suppression of their own interests and emotions but rather on the skilful development and cultivation of patronage and clientele relationships. Yet, the ostentatious demonstration and assertion of emotions was a decisive key in this matter.

So what is true? While the older, Weberian interpretation suggested that latitude for behaviour narrowed in office, the more a new ethos of duty developed and personal emotions made way for official routines, the younger, sociohistorical research would appear to claim the opposite, for patronage systems subsisted on those scopes that are attainable in office. 
They are based on networks that rely on personal relationships. Without emotionality, it is hard to imagine how such networks can be established and preserved. In the Spanish case, the situation was complicated by the fact that there is no unbroken line from the rise of the letrados to the modern state. Quite the contrary, already in the second half of the $16^{\text {th }}$ century and above all in the $17^{\text {th }}$ century, bourgeois office holders were often once again ousted by the nobility, especially in the higher offices of the court. At the same time, offices could now be bought, which undermined both the principle of selecting the best and clientelism, without completely overriding either. ${ }^{2}$ In all, the number of offices grew strongly, while the spectrum of types of office holding widened. For the mid- $17^{\text {th }}$ century, one can assume about 20,000 royal offices for peninsular Spain and a further ca. 16,500 positions in the American territories. ${ }^{3}$ The group of subaltern officials such as clerks, copyists, secretaries and secretariat staff also grew strongly. These infra-letrados (Jean-Marc Pelorson) often carried out the everyday administrative routines. ${ }^{4}$ Since new persons constantly had to be appointed to offices, the criterion of status often lost its significance in many areas. Instead, a person's suitability for office had to be demonstrated as a result of his or (rarely) her personal merits and qualities (méritos y calidades). ${ }^{5}$ This suitability for office was usually composed of different components, which varied depending on the prestige and functions of the office and also on the pool of candidates. As there was no such thing as the official per se, one should resist the temptation to construe an ideal type in hindsight. However, certain standard expectations concerning the personality and lifestyle of office holders emerged, particularly in this phase of the expansion of offices. Below we shall examine, based on the so-called corregidores, the expectations placed on personality, behaviour and emotionality and the function held by emotional self-control in the process.

\section{Behaviour and Emotionality of the Corregidores}

Corregidores were representatives of royal authority, sent by the king to the cities. They acted as judges and also had other controlling and administrative functions. ${ }^{6}$ Corregidores were always non-local and stayed only for a limited number of years in the city in which they exercised the corregimiento. This was intended to ensure that their loyalty to the king and their objectivity as judges were not weakened by social or emotional connections to the urban society whom they were to judge. In the $16^{\text {th }}$ century, corregimientos were occupied in almost equal measure by nobles and by letrados. Theoretically, some cities were to be occupied by letrados and others by caballeros, but this often varied in practice. The social position of a corregidor, therefore, cannot be derived simply from his noble rank. Rather, it was determined essentially on the basis of the person and his conduct as an office holder. ${ }^{7}$

It is therefore not surprising that questions concerning the suitability for this office and the appropriate forms of behaviour and emotions (pasiones, afectos) were an extensive topic in the tracts dealing with corregidores. By far, the most comprehensive tract was written by Jerónimo Castillo de Bobadilla (ca. 15461605). Despite his noble origins, he decided at an early age on a career as an office holder - first studied law in Salamanca and was initially corregidor in Soria and Guadalajara, then letrado of the Castilian estates and finally fiscal of the Chancillería in Valladolid. Ultimately, in 1597, he published a book about the office of the corregidores, the so-called Política para corregidores, which encompassed almost 2000 pages. In it, the ideal conduct of a corregidor was described: He should, it said, have a distinct sobriety (sobriedad), a moderate demeanour and maintain this moderation when eating and drinking. ${ }^{8}$ He should not engage in pastimes, listen to music or participate in trivial chatter. Otherwise he would be identified as a social climber and there would be talk of his slower quality ‘. ${ }^{9}$ Also in private encounters, he should not be observed dancing, playing an instrument or singing. This should not even happen in privacy. For, however trustworthy each society might appear, rumours of his conduct would always penetrate to the outside. He should refrain from all games, which would otherwise indicate a "great intimacy with the subjects ${ }^{10}$ His demeanour should never be loud and his step should be measured, heavy (grave) and quiet, yet not so slow as to appear pompous, and equally not in such haste as to cause breathlessness or flushed cheeks. 
When walking, the arms should not move excessively. Nor should his gaze roam permanently from one side to the other, since such gestures could signal lewdness or a lack of restraint. ${ }^{11}$ His clothing must always be clean and without defect, may be of shiny material but not of such colours that might suggest licentiousness. Curly or coloured hair should be avoided, as this signals femininity. ${ }^{12}$ The corregidor should engage in prayer, fear disgrace and seek honour. ${ }^{13}$

While this series of behavioural rules was aimed at distinguishing the corregidor from the society and its pleasures, it was also emphasised that he should never show disdain to the subjects or demonstrate unfriendliness. Also in other tracts, it was highlighted that corregidores, judges and other representatives of the king may not refuse conversations. Instead, just like the king himself, theoretically, they were to listen cordially to everyone, since ultimately the refusal of communication could be interpreted either as a sign of partiality or lack of interest in the duties that came with office. ${ }^{14}$ However, also this listening should be conducted with "reserve" (reserva), as too much sympathy could create obligations. ${ }^{15}$

Therefore, the behavioural art of the corregidor consisted of being present among city society in as neutral manner as possible. This allowed him to discourage any attempt by this society to decipher his feelings and inclinations and thus to question his impartiality. The "deadpan expression" of his face, as María Ángeles Martín Romera summarises it, "would reflect two qualities particularly associated with judges: impartiality and inaccessibility. In order to look impartial and inaccessible, the royal judge must exercise self-restraint, control over his own body and maintain an unreadable face « ${ }^{16} \mathrm{He}$ therefore ideally conducts himself, communicates and acts always literally - 'noncommittally, in other words in such a manner that suggests that he is not integrated into the society through which he walks. This was to be underlined by the preferably complete reduction of emotional expression, including the unconscious signals of the body, gait, head and arm movements, and by frustrating societal attempts to read and bind him. At the same time, this ensured that the same message was always sent, namely, that the function dominates, and the corregidor by nature is a judge, not a human.
Are we looking here at a prototype of »dehumanised « bureaucracy, whose specific character, according to Max Weber, develops all the more completely, the more »love, hate, all purely personal and all irrational elements of feeling, elements defying calculation" are eliminated from official business? ${ }^{17}$ Not only due to the state of research outlined above but also using the arguments of Max Weber, this cannot be the case, for bureaucracy is specifically modern and is markedly different from the time of the "gentlemen of the old order, inspired by personal interest, favour, grace, and gratitude $\omega^{18}$ The question therefore arises as to how we can explain such an older ostentation of disinterest and a lack of emotion historically. In the next section, I attempt to find an answer. I believe that this answer can be found only if one assumes a certain complexity, in other words by considering several models and functions.

\section{Models and Functions of the Lack of Emotion}

It does not require explanation that, in the Aristotelian tradition, the right measure of emotionality was demanded but rather that the instructions often go significantly beyond that. They idealise the lack or at least the invisibility of emotions. But how can such an escalation, towards the discarding of all affects, be explained? Models for such extreme positions can be detected in three areas, namely, in regard to kings, judges and clerics. On closer inspection, however, we can see that this often concerns only certain emotions or situations. For the clergy, in particular, it is an ambivalent matter: for in principle, affects pave the way to faith. But when these get out of hand or are oriented on the secular, they can soon turn into self-love or libidinous pleasure (concupiscentia) and thus lead to sin. At the same time, we also find here the monastic renunciation of earthly possessions, interpersonal ties, and the emotions these connections entailed. This is illustrated particularly clearly in a phrase that goes back to Jerome and was used later in mendicant and mystical contexts: One should ,follow naked the naked Christ (nudum Christum nudus sequere). ${ }^{19}$ Such nakedness, since it is regarded as a prerequisite for a beatific vision, is also known as contemplative nakedness (nuditas 
contemplativa). Its model in life is asceticism. It has nothing at all to do with physical needs but a lot with qualification for the higher principle, which is produced by the process of liberation from affects. The powerful idealisation of such a snakedness s of emotion on the part of the official, which is so noticeable in early modern Spain, thus follows this old motif, for example when councillors (consejeros) who "direct their attention solely to the common good, naked of affects and pretensions « ${ }^{20}$ are idealised. Similar images are used to describe a good corregidor. Castillo de Bobadilla notes how he felt »that I hung naked on the cross when I exercised public office, which in itself is a cross. And whoever administrates must be naked of all his own affects, but clothed by the love of many, in order to imitate the Son of God «. ${ }^{21}$ In this context, Castillo de Bobadilla warns against the four emotions listed already in the "Decretum Gratiani«, which pervert the human power of judgement: timor, cupiditas, odium and amor. ${ }^{22}$ These are emotions that are influenced strongly by interpersonal relationships. In order to defend against them, the corregidor should "always have God in mind «. ${ }^{23}$ This principle of a solum deum prae oculis habere therefore aligns the judge to a transcendental reference and distracts him from worldly references. Castillo de Bobadilla's corregidor is thus oriented on the archetype of an iudex perfectus. He is by necessity also a virtuous man. The scholastic bonus iudex tradition, which goes back to Thomas Aquinas, emphasises that it is not only legal technique that produces a good judge but also always personal virtue. ${ }^{24}$ This link between public office and virtuous persons corresponds to the conditions of a premodern justice of judges. In this system, societal expectations are concentrated much more strongly on the judge than on the still poorly developed legal institutions. ${ }^{25}$ Particularly in Spain, for example in the inquisition and the trials of residence (juicios de residencia), it was the individual judges who represented the law. For this matter, they always had to demonstrate its principles, in other words convey impartiality in their habitus and lifestyle and place themselves, to a certain degree, above a society driven by emotions and pervaded by conflicts. ${ }^{26}$

It is not possible here to present the entire complexity of the societal expectations on judges, the clergy or the court. What is essential is that it is the expectations of the others that are combined in these figures and that determine their scope for emotion. All three groups were subject to increased social observation: Insofar as they each administered a valuable good justice, salvation, favour, etc. the question continuously arose as to the criteria that applied and whether they were emotionally fickle or could even be manipulated. In terms of absolutist France, Jean de la Bruyère described quite strikingly this extreme attention to the smallest sign of affinity or aversion:

\section{Qu'un favori me fait moins attendre dans son antichambre que'à l'ordinaire, s'il a le visage plus ouvert, s'il fronce moins le sourcil, s'il m'écoute plus volontier, et s'il me reconduit un peu plus loin. je penserai qu'il commence à tomber, et je penserai vrai. $^{27}$}

In Spain, this problem of emotional manipulability was described as one of accessibility. Balthasar Gracián wrote "Feelings are the gate to the soul « ${ }^{28}$ Concealing these feelings meant keeping this gate closed. In this manner, emotional control and dissimulatio were the prerequisites for preventing manipulation by others and giving one's own reason the upper hand. ${ }^{29}$ Counsel given to the freshly enthroned Philipp III in 1598 illustrates clearly that this necessity to camouflage emotions also applied to the king. He was told that this was now the moment to "hide all of his inclinations and affects. All are watching with great care«. The counsellor added: "They should not know in which direction is to be fought, or how your wishes are to be met «. ${ }^{30}$

The maxims of successful emotional control, or at least the seamless masking of these affects, by no means applied solely to the court. In premodern clientelistic society, it potentially affected everyone and overlapped with the general idealisation of a dignified demeanour with reduced emotional display. The marked gravitas of public appearance was repeatedly noted by French travellers in particular, such as Antoine de Brunel in 1655:

Dans les ruës, à la promenade, à la Comedie, \& par tout où ils [the Spanish, A.B.] sont éclairez de plusieurs personnnes, ils sonst extrémement graves, posez, \& tout à fait retenus. En particulier quand on 
est familier avec eux, ils agissent d'un air si different du premier, qu'on ne croiroit pas que ce fussent les mesmes hommes. On les trouve aussi évaporez, aussi badins, \& aussi gaillards que ceux des autres Nations. $^{31}$

Not least, a publicly demonstrated reserved use of affects, and the great degree of self-control this implied, was regarded in the Spanish society as a specifically masculine virtue. ${ }^{32}$

In all, therefore, it is clear that the striking idealisation of a lack of emotion among Spanish corregidores can by no means be ascribed solely to a single tradition, such as that of the bonus iudex, or to a single function, such as demonstrating impartiality. Rather, it can be understood adequately only when we consider a broader range of political, cultural and social factors. These include the habitual commands of a society strongly influenced by clientelism and a courtly absolutist économie de la grâce. It demanded control over one's own physical and gestural signals, which would otherwise be read immediately as signs of favour or disfavour. It therefore idealised first and foremost the dissimulatio, the art of concealing one's own emotions.

Insofar as the corregidores represented the king and the law, such rules applied to them to a particularly strict degree. A greatly reduced use of affects was decisive for them, in order to safeguard the social construction of the office as such. It helped to close the gap between the person and the function of the office and in this way also to stabilise the fiction of objectivity. Where no emotions could be observed, there were no indications of personal motives or relationships, inclinations, weaknesses or possible corruptibility. However, how could it be ensured that the persons exercising public office lived accordingly, with their emotions held in check?

\section{Second Nature and Permanent Vigilance}

As mentioned, in the $16^{\text {th }}$ century, corregimientos were occupied in almost equal measure by nobles and letrados. Therefore, the virtues and conduct of the corregidores in general could not be ascribed credible, independent of status, and should correspond with the office itself. Castillo de Bobadilla therefore did not regard nobility itself as a precondition for office but rather the specific nature of the official, which should conform to the nature of the office (naturaleza del oficio). ${ }^{33} \mathrm{He}$ therefore developed the idea of a nobleza política. This "nobility of heroic customs" (nobleza de las heroycas costumbres), gained through education, virtues and the holding of office, should be preferred above that of noble blood..$^{34}$ This was not only an allusion to the popular idea, prevalent in the Siglo de Oro, of a nobleza de letras. ${ }^{35}$ Of greater interest is the fact that such a special nature of an office holder was supposed to develop over the course of a lifetime. Yet, this nature could take shape only when different elements interacted. Thus, the good corregidor should first have personal aptitudes such as diligence and virtue. An appropriate age should also have been reached, since young men, with the "vehemence of their passions", were deemed incapable of holding office. ${ }^{36}$ They would too easily succumb to passion, love, hate or ambition or to other affects that such a young age entails. ${ }^{37}$ Second, education and study should build upon these natural dispositions and the progression of time. This phase served by no means merely to acquire knowledge but also to practice habits that should then subsequently continue as consistently as possible. Ultimately, these costumbres should develop to become a second nature, which would then distinguish the corregidor significantly from the society over which he was to judge and administer. This sequence of stages over the course of a lifetime, composed of different elements, is illustrated well in a eulogy held for the deceased Martín Dávila in 1770. In it, he is described as a perfect, always disinterested judge, as a "judge of science, conscience and a lack of interest ${ }^{38}$ Already as a youth, Dávila was noted for his discretion. Via his family, one of the best in the city of Jerez de la Frontera, he had come into contact with many people from an early age. Yet even his closest relatives hardly knew him. He had spent his youth in college withdrawn, diligent, and modest. He despised any distractions that might compromise the all-too-fragile nature of man. ${ }^{39}$

However, a third element comes into play, both with Castillo de Bobadilla and in the eulogy cited above, namely, that of permanent, rigid self-control, a »vigilance 
over oneself « ${ }^{40}$ The fact that this vigilance is necessary shows clearly that neither the first nor the second nature was considered to be sufficient to represent the office personally and in a permanently stable manner. In addition, explained Castillo de Bobadilla, vigilancia was required. This vigilance was expressly necessary in order to "suppress the feelings and the human passions « ${ }^{41}$ It must be permanent, because the second nature created by education and habits was mistrusted. Over time, according to Castillo de Bobadilla, the weight of office fatigues the corregidor. If he fails to remain vigilant, the "reins of the natural inclination to evil" shall loosen. ${ }^{42}$ Two hundred years later, a tract on the corregidor perfecto used the same metaphors of the strict and permanent reining-in of oneself. ${ }^{43}$ In Martín Dávila's eulogy, there was a more precise description of how one should imagine this self-vigilance: "Enter into his heart, and you will see a kind of sanctuary, to which he withdrew daily in order to judge himself with the most rigid exactitude ${ }^{44}$

\section{Habitus and Vigilance: A Conclusion}

As we have seen, contemporary theory partially accepts the ssocial construct of the relevant characteristics of an office holder. It situates it precisely where modern sociology expects to find the development of the specific habitus, in other words in education and academic socialisation. At the same time, however, its argument is more complex, since the socialisation effect applies only under specific conditions. It applies only when, on the one hand, it can build on the base of naturally given dispositions and, on the other hand, when it is subjected ultimately to permanent and strict self-observation.

The focus on a total lack of emotion or interest, which is so confusing at the first glance, is therefore underpinned by a relatively realistic concept, which reflects the personal requirements of the office holder as well as his constantly endangered life praxis. The concept of a person without emotions or interests, in particular the motif of a snakedness from affects and the >disinterested person`, drew (like the concept of strict and permanent self-control) on models from religious practices.
These multiple references to the model of the clergyman appeared plausible in early modern times, especially since similar expectations of a demonstrable second nature were combined in the clergy and one could draw on a rich seam of motifs and practices there. We should, however, not overlook the differences. Whereas the church could offer a life perspective for those who renounced earthly goods, a royal official could not rely on an equally strong corporation. Ultimately, there was nothing comparable to the church in the secular area that could have effectively replaced family ties, a network of friends and patrons; on the contrary, both the courtly économie de la grâce and city society were based on relationship networks, from which not even the most perfect corregidor could have detached himself completely. It therefore makes sense for analytical reasons to go beyond the identification of such religious motifs and to concentrate more strongly on the social functions of distinctive forms of behaviour and affects.

It is worth recalling here the conundrum formulated at the outset, namely, that the ideal of an emotionless person, reduced completely to his official function, existed long before the age in which civil servants formed a social group. The ethos of the civil servant, therefore, cannot be understood as a consequence of the gradual formation of the relevant professional group. Rather, we can establish that anachronistic elements flowed into this ethos, including those that are much older than administration and statehood themselves.

If we refrain from thinking from the end, in other words from the fully developed civil service of Max Weber, but instead take the premodern as our starting point, it can be seen relatively easily which function was held by affect-reduced behavioural distinction. It was regarded precisely by a strongly clientelistic society as an impressive sign that the official had severed his emotional and economic connection to the society and was loyal to only one person (the king) and principle (justice). In this respect, it was not so much an absence of emotions per se but instead essentially a shifting of these emotions to just one love and loyalty, namely, to the crown and the law.

The ostentation of disinterestedness and emotional control, and of a life oriented on the pure function (for example of jurisprudence), therefore did not 
develop over the course of centuries alongside or as a consequence of state formation, the development of institutions and the emergence of civil servants as a social group. Rather, it had to emerge particularly intensively from the very outset, since a premodern clientelistic society had much greater expectations on the binding effect of emotions displayed in social interactions than a modern society. The fact that it did not naively assume, at the same time, that such a life, conceived against the rules of society and in part against human nature, cannot be realised consistently, can be seen from the fact that the elements of the formation of such an official nature, in other words virtue, education and habits, were supplemented by an instrument of self-control - the vigilancia sobre si mismo. 
1 José Antonio Maravall: "Los shombres del saber o letrados y la formación de su conciencia estamental«, in: José Antonio Maravall (ed.): Estudios de historia del pensamiento español. Bd. 1: Edad media, Madrid 1967, pp. 347-380; Pascal Gandoulphe: Au service du roi. Institutions de gouvernement et officiers dans le royaume de Valence (1556-1624), Montpellier 2005.

2 On the urban situation see: Francisco Tomás y Valiente: "La venta de oficios de regidores y la formación de oligarquías urbanas en Castilla (siglos XVII-XVIII)«, in: Historia. Instituciones. Documentos 2 (1975), pp. 525-547.

3 Jean-Pierre Berthe / Thomas Calvo (eds.): Administración e Imperio. El peso de la Monarquía hispana en sus Indias, 1631-1648, Zamora 2011, p. 73. The vast majority of officials were men; however, some women in court service with corresponding titles are known from as early as the 15th century, cf. William D. Phillips Jr.: "State Service in Fifteenth-Century Castile. A Statistical Survey of Royal Appointees«, in: Societas. A Review of Social History 8 (1978), pp. 115-136, at p. 117.

4 Jean-Marc Pelorson: Les sletrados‘. Juristes castillans sous Philippe III. Recherches sur leur place dans la société, la culture et l'état, Le Puy-en-Velay 1980.

5 Cf. José Ignacio Fortea Pérez: "Los corregidores de Castilla bajo los Austrias. Elementos para el estudio prosopográfico de un grupo de poder (1588-1633)«, in: Studia histórica. Historia moderna 34 (2012), p. 99-146, at pp. 102f., 124-134.

6 Fortea Pérez: "Los corregidores«; Marvin Lunenfeld: Keepers of the City. The Corregidores of Isabella I of Castile, 1474-1504, Cambridge 1987.

7 Pérez: "Los corregidores«, pp. 111-124.

8 Jerónimo Castillo de Bobadilla: Política para corregidores y señores de vasallos, en tiempo de paz, y de guerra, y para prelados en lo espiritual, y temporal entre legos, jueces de comision, regidores, abogados, y otros oficiales públicos: y de las jurisdicciones, preeminencias, residencias, y salarios de ellos: y de lo tocante a las ordenes, y caballeros de ellas, Bd. 1, Madrid 1775, p. 34

9 Castillo de Bobadilla: Política, p. 37.

10 Castillo de Bobadilla: Política, p. 37.

11 Castillo de Bobadilla: Política, p. 38.

12 Castillo de Bobadilla: Política, p. 40.

13 Castillo de Bobadilla: Política, p. 42.

14 Fadrique Furió Ceriol: El concejo y consejeros del príncipe. Estudio preliminar y notas de Henry Méchoulan, Madrid 1993, p. 54. Friendly, calm and attentive listening was demanded of Spanish kings and given accordingly. The Venetian ambassador Giovanni Soranzo reported in 1565 on Philipp II: »nel cammino che fa dalla camera alla chiesa dove ode la messa, piglia tutte le supplicazioni che le vengono date, e se alcuno le vuol parlare, si ferma cortesemente per udirlo. Il medesimo usa nell'uscir della chiesa [...]. Nel prender le suppliche si dimostra con faccia molto allegra, e se risponde ad alcuno, lo fa con cortesi e generali parole«, cf. Luigi Firpo (ed.): Relazioni di ambasciatori veneti al Senato. Tratte dalle migliori edizioni disponibili e ordinate cronologicamente, Bd. 8, Spagna (1497-1598), Turin 1981, p. 437; on the idealisation of the disinterested king: Jodi Campbell: Monarchy, Political Culture, and Drama in Seventeenth-Century Madrid. Theatre of Negotiation, Aldershot 2006, pp. 108, 126.

15 Thus, it was formulated by Sebastián Malvar, who in 1770, during a eulogy for the deceased Martín Dávila, praised him as a perfect, always disinterested judge. Cf. Sebastián Malvar: El juez de ciencia, de conciencia, y de desinteres. Oracion funebre en las exequias, que la grande Universidad de Salamanca celebró en su Real Capilla de San Geronymo el 16. de Junio de 1770, Salamanca 1770, p. 25.
16 María Ángeles Martín Romera: „Embodying royal justice in early modern Spain. Demeanour and Habitus in the instructions for the office of judge«, in: Kay Peter Jankrift et al. (eds.): Natur und Herrschaft: Analysen zur Physik der Macht, Berlin, Boston 2016, pp. 251-274, at p. 252.

17 Max Weber: Wirtschaft und Gesellschaft. Grundriss der verstehenden Soziologie, Tübingen 1980, p. 563.

18 Weber: Wirtschaft 1980, p. 563.

19 Réginald Grégoire / Aimé Solignac: „Nudité«, in: Dictionnaire de spiritualité 11 (1982), pp. 507-518.

20 "Según lo cual serán mejores para consejeros, los que, desnudos de afectos y de pretensiones, pusieren la mira en sólo el bien público«, cf. Pedro Fernández Navarrete: Conservacion de monarquias y discursos políticos sobre la gran consulta que el consejo hizo al señor Don Felipe tercero al presidente, y consejo supremo de Castilla, Madrid 1626, p. 40.

21 "y note que fue puesto desnudo en la cruz, quando exercito Oficio publico, el qual es cruz, y el que administra ha de estar desnudo de todos los afectos proprios, y vestido del amor de los muchos, para imitar al hijo de Dios«, cf. Castillo de Bobadilla: Política, p. 267.

22 Here, Carlos Garriga: "Crimen corruptionis. Justicia y corrupción en la cultura del ius commune (Corona de Castilla, siglos XVI-XVII)«, in: Revista Complutense de Historia de América 43 (2017), pp. 21-48, at p. 23.

23 Castillo de Bobadilla: Política, p. 267.

24 Carlos Garriga: "Iudex perfectus. Ordre traditionnel et justice de juges dans l'Europe du ius commune (Couronne de Castille, XVeXVIIIe siècle)«, in: Histoire des justices en Europe 1 (2016), pp. 7999; Wilfried Küper: Die Richteridee der Strafprozessordnung und ihre geschichtlichen Grundlagen, Berlin 1967, pp. 88-90.

25 Cato van Paddenburgh: "The ideal judge in the 17th century: the example of Gabriel Álvarez de Velasco's Iudex Perfectus«, in: Glossae. European Journal of Legal History 14 (2017), pp. 648-659, at p. 653.

26 Arndt Brendecke / María Ángeles Martín Romera: „El habitus del oficial real. Ideal, percepción y ejercicio del cargo en la Monarquía Hispánica«, in: Studia histórica. Historia moderna 39/1 (2017), pp. 23-51.

27 Jean de La Bruyère: Les Caractères, Bd. 1, Paris 1805, p. 201.

28 Cantarino, Elena: »Pasión y razón en Baltasar Gracián (a propósito de algunas alegorías de sel criticón`)«, in: Atilano Domínguez (ed.): Vida, pasión y razón en grandes filósofos, Cuenca 2002, p. 71-92, at p. 88; Jean-François Senault also describes precisely the problem of the manipulability of the person whose feelings are known: »Ie sçay bien que la Politique nous enseigne des moyens pour arriver a cette connoissance, [...]: On iuge des sentiments par les actions, on lit dans les yeux \& sur le visage les plus secrets mouvemens de l'ame: on remarque le naturel par les desseins, on estudie si bien les hommes qu'on devine leurs pensées, \& qu'on découvre par un artifice ce qu'ils veulent cacher par un autre. Mais de toutes ces voyes, je ne trouve point de plus facile ny de plus asseurée que celle des Passions, car elles échapent contre notre volonté«, cf. Jean-François Senault: De I'usage des passions, Lyon 1669, p. 149.

29 On the dissimulation, see inter alia Fernando de la Flor: Pasiones frías. Secreto y disimulación en el Barroco hispano, Madrid 2005, pp. 123-139.

30 "Que ahora es tiempo que [...] ha de encubrir Vuestra Majestad todas sus inclinaciones y afectos, que miran todos con gran cuidado, para que no sepan por dónde han de combatir y cómo se han de prevenir contra sus deseos." Cf. Baltasar Álamos de Barrientos: 
Discurso político al rey Felipe III al comienzo de su reinado. Edición de Modesto Santos, Barcelona 1990, p. 80.

31 Antoine de Brunel: Voyage d'Espagne, contenant entre plusieurs particularitez de ce royaume, trois discours politiques sur les affaires du Protecteur d'Angleterre, la Reine de Suede, \& du Duc de Lorraine, Köln 1666, p. 74.

32 Mar Martínez Góngora ascribes this in particular to the Erasmus reception, which began in the 1520s, and the associated formation of a new ideal of masculinity, cf. Mar Martinez Gongora: El hombre atemperado. Autocontrol, disciplina y masculinidad en textos españoles de la temprana modernidad, New York 2005.

33 There are abundant metaphors on the nature of public office, e.g. in Francisco Bermúdez de Pedraza: El secretario del rey, Madrid 1620 [ND Madrid 1973] and Juan Josef Sánchez: Nobleza, privilegios y prerogativas del oficio público de escribano, Bd. 3, Valencia 1798.

34 Castillo de Bobadilla: Política, p. 31.

35 Pelorson: Les >letradosı, pp. 141-143.

36 Here the text follows the iudex est senex argumentation, cf. on this point Küper: Die Richteridee, p. 87.

37 Castillo de Bobadilla: Política, p. 97.

38 "juez de ciencia, de conciencia, y de desinteres«.

39 Malvar: El juez de ciencia, 1770, pp. 10-25.

40 »vigilancia sobre si mismo«, cf. Malvar: El juez de ciencia, 1770, p. 34.

41 "gran vigilancia para reprimir los afectos, y pasiones humanas", Castillo de Bobadilla: Política, p. 249.

42 Castillo de Bobadilla: Política, p. 249.

43 Lorenzo Guardiola y Sáez: El corregidor perfecto [...], Madrid 1776, p. 16.

44 »Entrad en su corazon, y vereis una especie de santuario, a donde se retiraba todos los dias, para juzgarse con la mas rigida exactidud«, cf. Malvar: El juez de ciencia, p. 34. 


\section{Abstract}

The essay is dedicated to the idealized emotionlessness of early modern Spanish office holders. It focuses on the so called corregidores, which represented the king and administered justice in major Spanish cities. Their instructions often idealized the total lack of pasiones or at least their complete invisibility. Such a discarding of all affects echoed the ideals of impartial judges, just kings and uninterested clerics and had specific functions, especially in cities with their high density of mutual observation. To live accordingly, that is, with one's own emotions permanently held in check, required personal aptitude, appropriate age and a process of education and study which should convert certain habits into a ssecond nature the corregidor significantly from the society over which he was to judge. Constantly checked by society however, this second nature would corrupt, if not protected by a rigid and permanent »vigilance over oneself».

\section{About the Author}

Arndt Brendecke is professor of early modern history at the University of Munich (LMU). His research focusses on the cultural history of Europe, on the Spanish colonial rule in Latin America and on intellectual, political and administrative techniques of knowledge. He has recently published a study on the relationship between knowledge and colonial power (The Empirical Empire: Spanish Colonial Rule and the Politics of Knowledge.Berlin, Boston 2016). 